\title{
RESEARCH ON THE DEMAND FOR PARKING LOTS OF SHOPPING CENTRES
}

\author{
Vytautas Palevičius, Marija Burinskienė, Valentinas Podvezko, \\ Gražvydas Mykolas Paliulis, Edita Šarkienė, Jonas Šaparauskas
}

\section{Introduction}

A high level of car ownership in large cities of Lithuania caused a great shortage of parking spaces in multi-storey housing areas. The car ownership level in Klaipeda is 506 cars/1,000 inhabitants, in Kaunas - 547, in Šiauliai - 490, in Panevéžys - 528 and in Vilnius - 474 (see Fig. 1). More and more residential districts face a problem of the abundance of cars standing right beside residential houses. This is dangerous from the road safety point of view as they block the driveways, sidewalks and green spaces, and considerably worsens the quality of life for local residents. One of the ways to reduce the demand for parking lots in urbanized areas is to use the parking lots of adjacent shopping centres.

Construction of the shopping centres was encouraged by the growth of economy in the cities of Lithuania over the recent decades. In 1995, the first shopping centres were opened in large Lithuanian cities the majority of which were built in peripheral zones of the city. This ensured good accessibility, variety of goods and services, free parking of cars. The development of shopping centres in a periphery satisfied the needs of investors - to acquire cheaper land, uncomplicated design and construction, quick payback of investments. A transport infrastructure was erected - streets and pedestrian paths were built (Burinskiene \& Munch, 2003).

The largest construction of shopping centres in Vilnius took place in 2000-2010 when their number increased three times. Based on data of 2014, the total area of shopping centres in Vilnius amounted to more than 400 thousand square meters. Based on the Lithuanian

Fig. 1: Dynamics in the level of car ownership in the largest cities of Lithuania

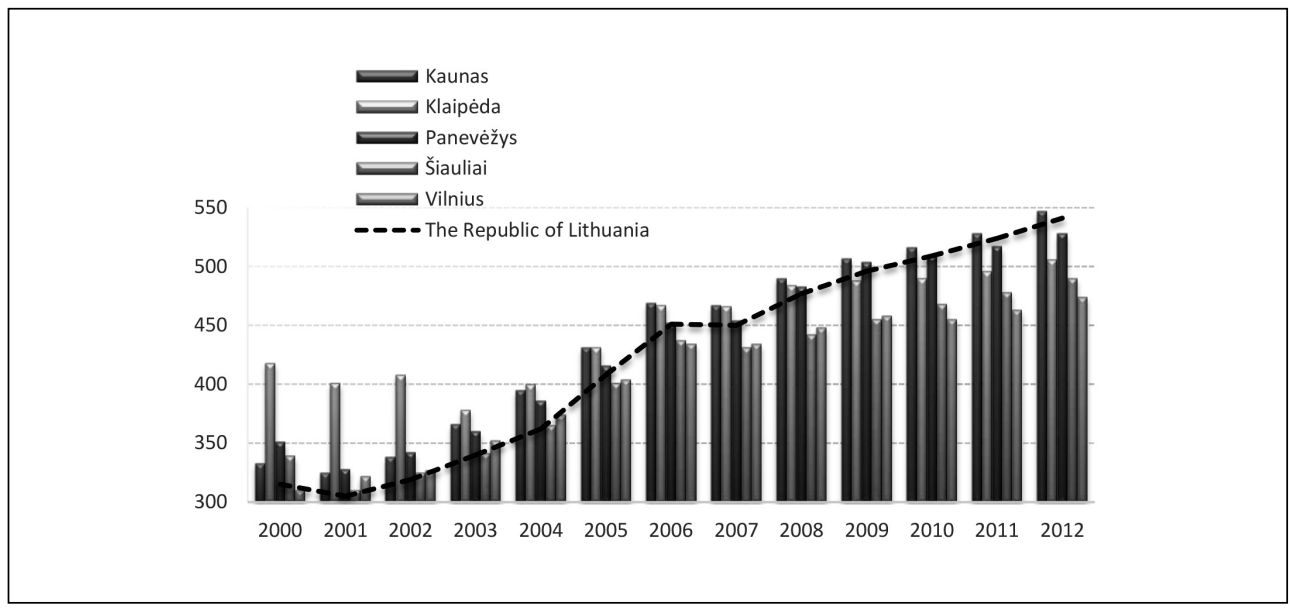


Construction Technical Regulation (STR) the shopping centre shall ensure the minimum number of parking spaces, $20 \mathrm{~m}^{2}$ area of the shopping shall be accommodated with 1 parking space (Zagorskas \& Palevičius, 2011).

Unlike the laws in many other countries, the laws of Lithuania allow to build shopping centres of various size in residential districts. At night, parking lots near those shopping centres are almost empty, whereas, the residents of adjacent multi-storey houses lack parking spaces near their houses. Our aim is to develop an evaluation system of shopping centre parking lots, which would enable to solve problems related to the lack of parking spaces near multi-storey houses.

Intensive use of the parking lots of shopping centres will allow reducing the number of parking spaces in the urbanized areas, to release the multi-storey residential areas from the chaotically parked cars and to create favourable and safe conditions for pedestrians, public transport and service vehicles.

\section{Literature Review}

The literature review of the shopping centre parking's lots is divided into two groups. In the first group the scientific work is overviewed and in the second group - pilot projects.

\subsection{The Scientific Works}

The scientists from Netherlands made the research - Is parking supply related to the turnover of shopping areas? (Mingardo \& Van Meerkerk, 2012). For the research purposes they selected 80 parking lots of shopping centres and determined that the size of parking lot has no effect on the turnover of the shopping centre. However, the most important factors are quantity and quality of the shops, visitorfriendliness, location and accessibility.

The Scottish scientist, analysing the relative importance of nine agglomeration format characteristics on the attractiveness of shopping malls and shopping streets, found out that retail tenant mix and atmosphere has the highest relative importance. He concluded also that parking does not seem "to provide potential to change the attractiveness of the investigated agglomeration factors" (Teller, 2008).

The Australian scientist raised five hypotheses: 1) Consumers will rate parking and access convenience as an important determinant of where they choose to shop;
2) Consumers will rate parking and access as important irrespective of age, income or gender; 3) Consumers will perceive malls as offering better access and parking convenience than strips; 4) Parking and access convenience will influence retail centre preference; 5) Parking and access convenience will influence consumers most frequented retail format. The author concluded, that the findings indicate that urban planners must give careful consideration to the negative consequences that may stem from strategies designed to deter car-based shopping (Reimers, 2013).

\subsection{Pilot Projects}

In the works of foreign scientists a differentiation of the demand for parking lots of shopping centres has not been widely studied (Czerwinski, 2013). More widely studied are the demand and possibilities for the construction of multi-storey garages at large shopping centres (Pech et al., 2009), the use of the parking lots of shopping centres for Park\&Ride system, implementation of Carfree Cities concept, and the like (Hole, 2004).

Many authors from EU countries pay their attention to the fact that shopping centres are provided with underground and over-ground garages: Hamburg, Stockholm, Helsinki, Vienna, London, Oxford, Warsaw (Szarata, 2007; Pęski \& Czechowski 2001), Cracow (Kęsek, 2007) which accommodate 2,000-5,000 cars. Since in foreign countries the shopping centres are built further from residential areas (Kanajan et al., 2005) their parking lots are used only by the shopping centre visitors of (see Fig. 2).

When solving car parking problems in urbanized areas the multi-storey underground garages are built, a top priority is given to the development of public transport as an alternative to passenger car (Wang et al., 2004).

In recent decade, in the West European cities the concept of Carfree Cities is popular (Crawford, 2000), based on which the cars are eliminated from the multi-storey residential districts giving priority to public transport and expanding green spaces. Residential districts that are free of parking spaces are erected in Edinburg, Hamburg (Petersen, 2009), Freiburg, Amsterdam, Malmo. The cars are parked on the outside streets of residential districts, in multi-storey garages. At present, it is important to organize a convenient public transport and a network of cycle paths. In recent years, in the cities of United Kingdom, Germany, 


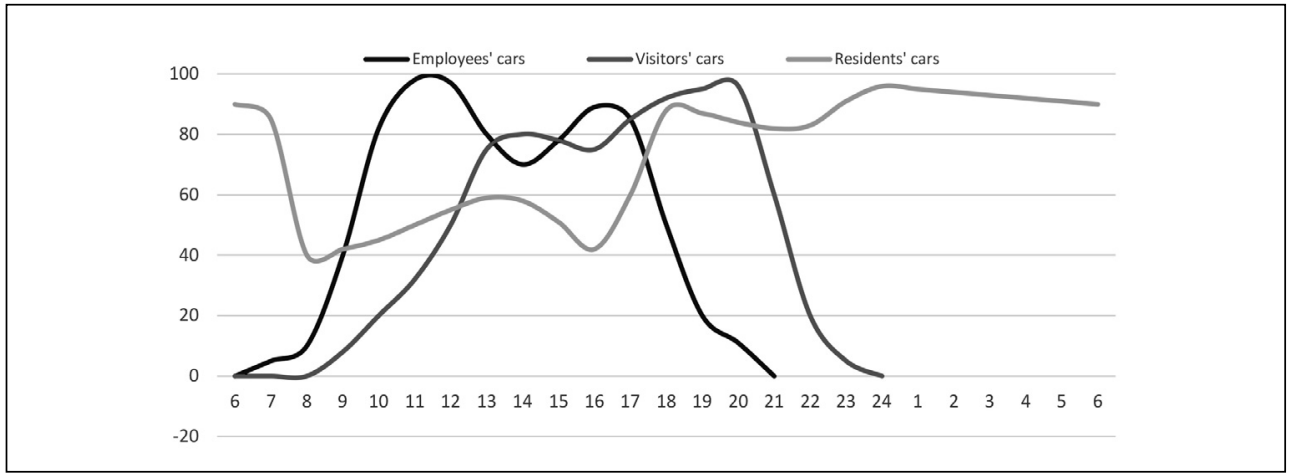

Source: Kanajan et al. (2005)

Italy, Czech and other countries a system of combined journeys is being implemented by using the compatible passenger car and public transport, including railway, resulting in the implementation of Park\&Ride and Park\&Rail systems (Majdecka et al., 2012).

Many authors emphasize in their studies that parking problems in the urbanized areas must be solved in a complex way taking into consideration the living quality of residents which is worsened by cars left standing in the prohibited places at the residential houses: in the territories of green spaces, children's playgrounds, etc. (Parteka, 2010).

\section{Research Methodology}

The aim of this work is to ensure the effective twenty-four-hour use of the parking lots of shopping centres, situated in the multi-storey housing areas, for parking of passenger cars. To implement this aim the main criteria are determined influencing the use of the parking lots of shopping centres by the local residents.

The following tasks were raised to reach the aim of work:

- To make a review of foreign scientific literature.

- To carry out investigation of parking regularity in the parking lots of shopping centres adjacent to multi-storey housing areas, taking into consideration the need of local residents to use them at night.

- To assess the results of multi-criteria decision making approach.
The following research methods were used: empirical, expert and multi-criteria: SAW, TOPSIS, PROMETHEE.

Until now, no detail investigations were carried out at the shopping centres to determine the car parking parameters and characteristics. Today, very often the cars that are not admitted to the parking lots of shopping centres are parked on the streets and adjacent yards of residential houses, and after the shopping centres are closed their parking lots are almost empty throughout the whole night. A complex use of these parking lots and rotation of cars would reduce the number of passenger cars standing on the streets of residential districts (Palevičius et al., 2013).

At present, in Vilnius the number of parking spaces at all shopping centres, including the largest shopping and recreational centres, is more than 20,000 of which only about 5,400 $(27 \%)$ are occupied with passenger cars at night (see Fig. 3).

Observations of the parking of cars were carried out in the parking lots of 49 Vilnius City shopping centres and within a 300 metre radius of shopping centres (see Fig. 4).

The research was carried out in September - October 2013 using the observation method. The research of parking spaces has its own specific features, therefore observations were carried out during working days, except Fridays and weekends. During the observation it was determined: a design capacity of parking lots of shopping centres, the occupancy of the lot, 

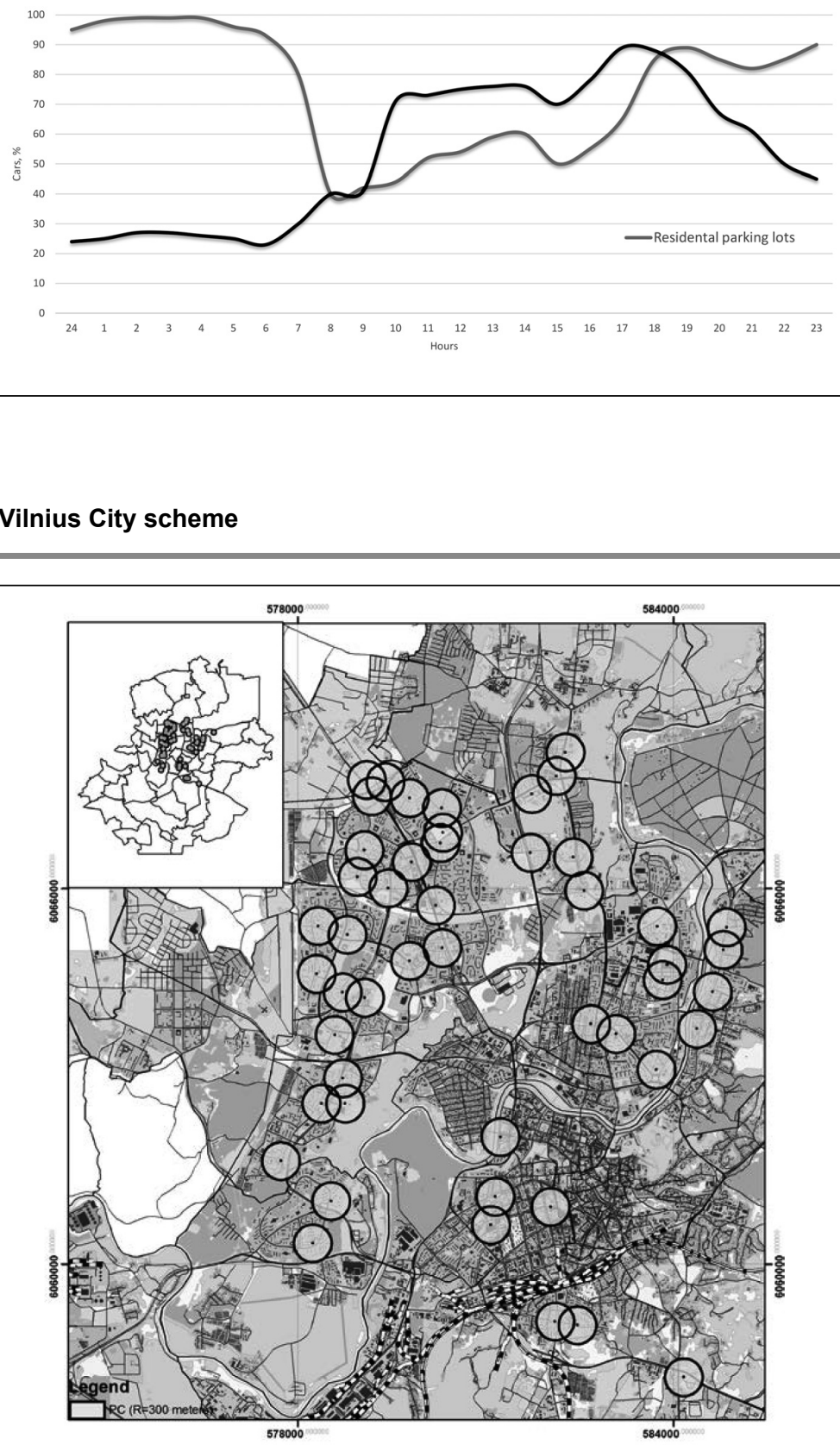


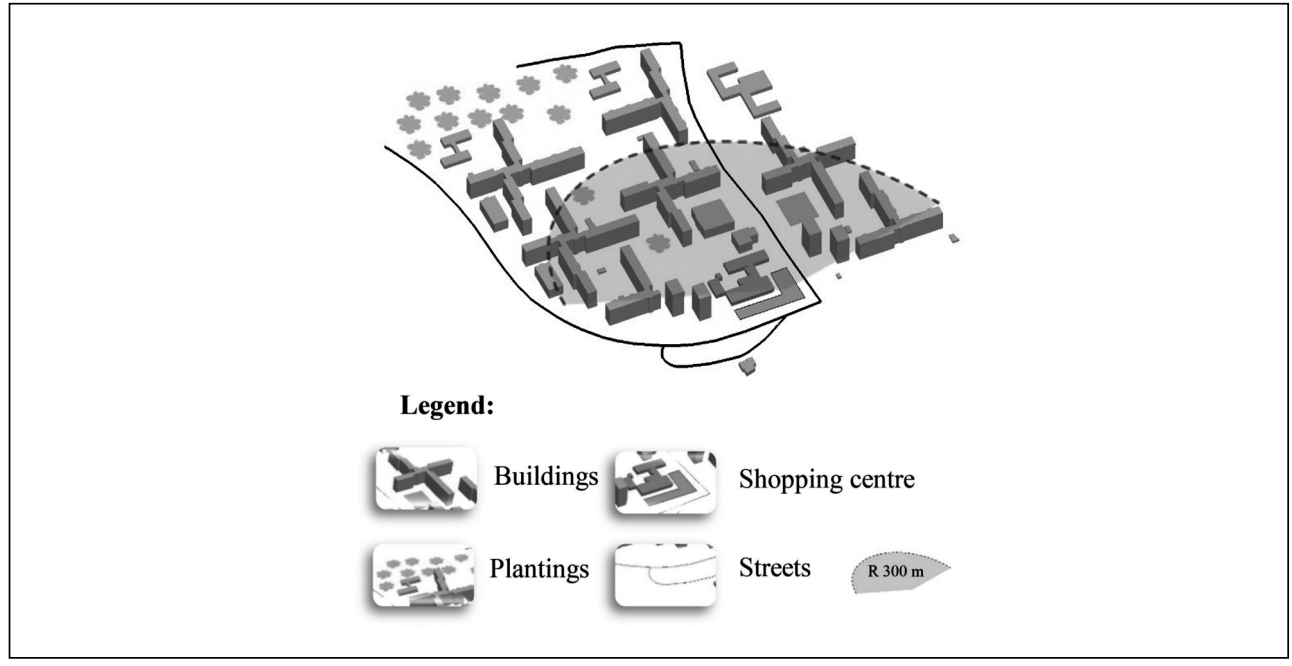

Source: own

the number of residents and flats, the value of flats, the number of working population, the demand for parking spaces (the research on the occupancy of parking spaces was carried out at night from 10.00 p.m. to 2.00 a.m.), etc. Additionally, the main criteria were selected in order to determine the interaction of the parking lots of shopping centres with the neighbouring area (R $300 \mathrm{~m})$. An example of research scheme is given in Figure 5.

During preliminary analysis in a visual way and based on the marking of parking spaces the real number of parking spaces was determined in the parking lots of shopping centres as well as their design capacity. In the absence of marking the exact number of parking spaces was determined with the help of GIS technologies (Jakimavičius \& Burinskienè, 2010).

From 10.00 p.m. to 2.00 a.m. at night in a sequence order in all study objects the number of free parking spaces was recorded.

The value of occupancy or loading of the lot was determined by the following formula:

$$
p_{\text {st. }}=a-I+n \text {, }
$$

The occupancy coefficient of the parking lot in the certain time intervals is used to show the ratio between the number of cars parked in the parking lot in the certain moment and the existing number of parking spaces.

$$
k=\frac{p_{s t .}}{a}
$$

For the rational functioning of a parking lot this value would not exceed 0.8 . When the occupancy is more than 0.8 - the functioning of a parking lot is aggravated, the problems of road safety appear; when the value exceeds $1.00-$ the parking process in many cases becomes uncontrolled. Also, a percentage expression of the occupancy value can be used.

The parking lots of shopping centres, that are qualified as high attraction objects, allow the residents of multi-storey houses to use them at night for their own needs, e.g., for a long-term or short-term storage of cars. The detail investigations showed that the occupancy of the study parking lots at night varies from 1 to $115 \%$. It is obvious that the occupancy coefficients for the parking lots of shopping centres are different, therefore, the authors divided the study parking lots into four groups (see Fig. 6).

The group I covers eight parking lots of shopping centres, the group II -8 , the group III -13 and the group IV -20 . Depending on the 


\section{Fig. 6: Percentage occupancy of the parking lots of shopping centres by groups}

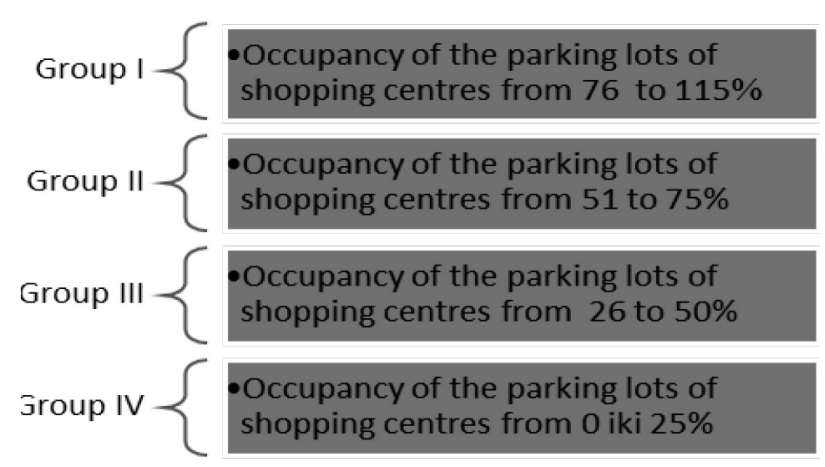

Source: own

housing development of the urbanized areas the demand for the parking lots of shopping centres in the cities are different. Frequently, the total area is not as important as the nature of functioning of certain places which is described by the turnover of one car parking space. Therefore, it is important to confirm or deny a hypothesis that a systematic development of the parking lots of shopping centres will allow to solve parking problems in the urbanized areas. This investigation is related to the belief that it will give positive results. The main indices are selected which allow assessing the situation in the study micro-environment and determining the relation of the existing parking lots of shopping centres to the environment of the district. In this work 7 criteria were selected:

- Intensity of housing development (K1) a ratio between the sum of the total area of over ground premises of all buildings and the total area of land plot, expressed in percent $(\%)$.

- Width of the carriageway of streets situated at the shopping centres (K2). At the parking lots of shopping centres, which were divided by arterial streets and the streets of lower categories, a width of the carriageway was measured (in meters).

- Number of flats (K3) was determined based on the information given by the Statistics Lithuania, expressed in a number of flats.

- Value of flats (K4) was calculated based on data provided by the company Codeln, UAB.
- Direct visibility of the parking lot from the surrounding flats (K5) was calculated with the help of GIS, expressed in percent.

- Working population (K6) was determined based on the information given by the Statistics Lithuania, expressed in units.

- The demand for parking spaces (K7) was calculated according to the minimum requirements to the erection of parking spaces at multi-storey houses; based on the Construction Technical Regulation STR 2.06.04:2014 Streets and Roads of Local Significance. General Requirements.

All those criteria were determined and calculated within a 300 metre radius of the parking lot of shopping centres.

The group I involves eight parking lots of shopping centres the occupancy of which at night varies from 83 to $115 \%$ (Tab. 1).

The group II covers eight parking lots of shopping centres the occupancy of which at night varies from 54 to $67 \%$ (Tab. 2).

The group III involves thirteen parking lots of shopping centres the occupancy of which at night varies from 27 to $48 \%$ (Tab. 3).

The Group IV covers twenty parking lots of shopping centres the occupancy of which at night varies from 1 to $23 \%$ (Tab. 4).

For further calculations the Multiple-Criteria Decision Making techniques (MCDM) were used. 


\begin{tabular}{|c|c|c|c|c|c|c|c|}
\hline Tab. 1: & $\begin{array}{l}\text { The va } \\
\text { of sho }\end{array}$ & $\begin{array}{l}\text { of the } \\
\text { centr }\end{array}$ & $\begin{array}{l}\text { ia of oc } \\
\text { group }\end{array}$ & ancy pot & f for $t$ & king lo & \\
\hline No. & $\mathbf{K}_{1, \%}$ & $\mathrm{~K}_{2, \mathrm{~m}}$ & $\mathbf{K}_{3, \text { vnt. }}$ & $K_{4, L t . / m^{2}}$ & $\mathbf{K}_{5, \%}$ & $\mathbf{K}_{6, \text { vnt. }}$ & $\mathbf{K}_{7, \%}$ \\
\hline 1 & 1.36 & 34 & 2,480 & 2,670 & 17 & 2,350 & 239 \\
\hline 2 & 0.95 & 70 & 1,610 & 3,448 & 11 & 1,880 & 505 \\
\hline 3 & 0.79 & 6 & 1,430 & 2,670 & 17 & 1,350 & 241 \\
\hline 4 & 1.48 & 24 & 2,480 & 2,734 & 14 & 3,150 & 259 \\
\hline 5 & 1.08 & 14 & 1,720 & 2,705 & 18 & 2,470 & 542 \\
\hline 6 & 0.42 & 13 & 720 & 3,402 & 9 & 960 & 492 \\
\hline 7 & 1.03 & 14 & 2,220 & 3,489 & 10 & 1,780 & 373 \\
\hline 8 & 1.01 & 20 & 1,700 & 2,730 & 19 & 2240 & 256 \\
\hline
\end{tabular}

\begin{tabular}{|c|c|c|c|c|c|c|c|}
\hline Tab. 2: & $\begin{array}{l}\text { The v } \\
\text { of sho }\end{array}$ & $\begin{array}{l}\text { the } \\
\text { entr }\end{array}$ & $\begin{array}{l}\text { a of oc } \\
\text { group I }\end{array}$ & incy po & for & king & \\
\hline No. & $\mathbf{K}_{1, \%}$ & $\mathrm{~K}_{2, \mathrm{~m}}$ & $\mathrm{~K}_{3, \text { vnt. }}$ & $K_{4, \text { Lt } / \mathrm{m}^{2}}$ & $\mathbf{K}_{5, \%}$ & $\mathbf{K}_{6, \text { vnt. }}$ & $\mathbf{K}_{7, \%}$ \\
\hline 1 & 0.92 & 14 & 1,610 & 2,635 & 17 & 1,580 & 369 \\
\hline 2 & 1.03 & 13 & 1,640 & 2,757 & 9 & 2,310 & 255 \\
\hline 3 & 0.53 & 40 & 950 & 2,738 & 6 & 1,250 & 467 \\
\hline 4 & 0.63 & 14 & 1,320 & 3,448 & 3 & 1,060 & 390 \\
\hline 5 & 0.96 & 34 & 1,760 & 2,659 & 11 & 1,750 & 455 \\
\hline 6 & 0.13 & 7 & 20 & 2,635 & 0 & 140 & 221 \\
\hline 7 & 0.33 & 30 & 590 & 4,151 & 40 & 690 & 463 \\
\hline 8 & 0.73 & 33 & 1,290 & 3,837 & 0 & 1,710 & 221 \\
\hline
\end{tabular}

Source: own

\begin{tabular}{|c|c|c|c|c|c|c|c|}
\hline \multirow{2}{*}{$\begin{array}{l}\text { Tab. } 3 \\
\text { No. }\end{array}$} & \multicolumn{7}{|c|}{$\begin{array}{l}\text { The values of the criteria of occupancy potential for the parking lots } \\
\text { of shopping centres in group III }\end{array}$} \\
\hline & $\mathbf{K}_{1, \%}$ & $\mathrm{~K}_{2, \mathrm{~m}}$ & $\mathbf{K}_{3, \text { vnt. }}$ & $K_{4, L t / m}{ }^{2}$ & $\mathbf{K}_{5, \%}$ & $\mathbf{K}_{6, \text { vnt. }}$ & $\mathbf{K}_{7, \%}$ \\
\hline 1 & 0.43 & 8 & 680 & 2,949 & 5 & 970 & 260 \\
\hline 2 & 0.35 & 10 & 520 & 3,267 & 30 & 830 & 282 \\
\hline 3 & 0.76 & 6 & 1,290 & 3,463 & 0 & 1,770 & 234 \\
\hline 4 & 0.70 & 0 & 1,390 & 3,474 & 8 & 1,220 & 417 \\
\hline 5 & 0.77 & 35 & 1,330 & 2,696 & 9 & 1,510 & 249 \\
\hline 6 & 1.04 & 7 & 1,880 & 2,710 & 15 & 1,890 & 169 \\
\hline 7 & 0.55 & 27 & 1,020 & 3,779 & 11 & 1,140 & 446 \\
\hline 8 & 0.35 & 14 & 730 & 3,345 & 0 & 630 & 390 \\
\hline 9 & 0.64 & 15 & 1,150 & 2,614 & 19 & 1,070 & 352 \\
\hline 10 & 0.45 & 7 & 770 & 2,659 & 11 & 920 & 491 \\
\hline 11 & 0.28 & 27 & 480 & 2,730 & 22 & 570 & 187 \\
\hline 12 & 0.71 & 21 & 1,410 & 3,345 & 8 & 1,170 & 414 \\
\hline 13 & 0.82 & 66 & 1,530 & 2,670 & 31 & 1,400 & 233 \\
\hline
\end{tabular}




\begin{tabular}{|c|c|c|c|c|c|c|c|}
\hline Tab. 4: & $\begin{array}{l}\text { The v } \\
\text { of sho }\end{array}$ & $\begin{array}{l}\text { f the } \\
\text { cent }\end{array}$ & $\begin{array}{l}\text { a of oc } \\
\text { group I }\end{array}$ & ancy po & for $t$ & king lo & \\
\hline No. & $\mathbf{K}_{1, \%}$ & $K_{2, m}$ & $\mathbf{K}_{3, \text { vnt. }}$ & $\mathrm{K}_{4, \text { Lt./m }}{ }^{2}$ & $\mathbf{K}_{5, \%}$ & $\mathbf{K}_{6, \text { vnt. }}$ & $\mathbf{K}_{7, \%}$ \\
\hline 1 & 0.17 & 0 & 310 & 3,345 & 25 & 400 & 458 \\
\hline 2 & 0.95 & 48 & 1,590 & 2,721 & 0 & 2,050 & 258 \\
\hline 3 & 0.72 & 16 & 1,170 & 3,219 & 14 & 1,530 & 526 \\
\hline 4 & 0.49 & 23 & 870 & 3,631 & 12 & 1,030 & 475 \\
\hline 5 & 0.21 & 40 & 410 & 3,527 & 25 & 470 & 432 \\
\hline 6 & 0.33 & 50 & 590 & 2,735 & 8 & 630 & 170 \\
\hline 7 & 0.89 & 15 & 1,580 & 2,690 & 20 & 1,800 & 238 \\
\hline 8 & 0.27 & 9 & 450 & 2,782 & 8 & 650 & 243 \\
\hline 9 & 0.61 & 21 & 1,170 & 3,345 & 14 & 1,450 & 105 \\
\hline 10 & 0.44 & 22 & 700 & 3,097 & 18 & 920 & 540 \\
\hline 11 & 0.29 & 39 & 580 & 3,345 & 50 & 590 & 419 \\
\hline 12 & 0.67 & 20 & 1,140 & 4,212 & 3 & 1,530 & 496 \\
\hline 13 & 0.04 & 42 & 70 & 1,666 & 0 & 90 & 543 \\
\hline 14 & 0.34 & 42 & 570 & 3,413 & 9 & 810 & 516 \\
\hline 15 & 0.17 & 52 & 180 & 4,190 & 0 & 280 & 847 \\
\hline 16 & 1.04 & 18 & 2,000 & 3,307 & 14 & 1,900 & 433 \\
\hline 17 & 0.13 & 0 & 220 & 3,135 & 0 & 280 & 493 \\
\hline 18 & 0.34 & 22 & 540 & 3,283 & 23 & 780 & 541 \\
\hline 19 & 0.53 & 11 & 840 & 2,962 & 8 & 1,320 & 260 \\
\hline 20 & 0.28 & 18 & 540 & 2,670 & 0 & 480 & 222 \\
\hline
\end{tabular}

\section{The Use of Multiple-Criteria Methods}

The multiple-criteria problems are solved by various mathematical methods. The multiplecriteria problems have from several to several tens of criteria and when making the decision all of them must be considered. To assess the criteria of occupancy potential of the parking lots of shopping centres three multiple-criteria methods were used: SAW, TOPSIS and PROMETHEE. Each method uses different ideas of data normalization and transformation.

\subsection{Determination of the Significance of Criteria}

Having made an empirical research of 49 shopping centre parking lots the list of decisive criteria was made having the effect on the occupation of the parking lots of shopping centres. The list of criteria was made in a way of expert evaluation, i.e. 4 groups of scientists selected 7 main criteria, which were later presented to the experts. For expert evaluation the expert questioning was carried out where 8 experts took part, 4 of them are the specialists in transport sector, 3 specialists of territorial planning and 1 architect. The respondents work in both public and private sector. The average working experience of the respondents is more than 15 years.

The experts made a ranking of criteria by the preference order in respect of their significance to the research object. The most significant criterion was given the highest value equal to one, the next criterion (according to its effect on the research object) got the value 2, and so on; the least significant index got the value $\mathrm{m}$, where $\mathrm{m}$ - the number of criteria used. Ranking makes it possible for the experts to distinguish the most significant and insignificant criteria and to assess the significance of 


\begin{tabular}{|c|c|c|c|c|c|c|c|c|c|c|}
\hline \multirow{2}{*}{$\boldsymbol{m}$} & \multicolumn{8}{|c|}{ Experts } & \multirow{2}{*}{$e_{i}$} & \multirow{2}{*}{$v$} \\
\hline & $r_{1}$ & $r_{2}$ & $r_{3}$ & $r_{4}$ & $r_{5}$ & $r_{6}$ & $r_{7}$ & $r_{8}$ & & \\
\hline 1 & 2 & 2 & 6 & 4 & 4 & 3 & 3 & 6 & 30 & $3-4$ \\
\hline 2 & 5 & 6 & 7 & 5 & 6 & 6 & 7 & 4 & 46 & 6 \\
\hline 3 & 3 & 4 & 3 & 7 & 2 & 4 & 2 & 5 & 30 & $3-4$ \\
\hline 4 & 7 & 7 & 5 & 6 & 7 & 7 & 6 & 3 & 48 & 7 \\
\hline 5 & 6 & 3 & 4 & 3 & 5 & 2 & 5 & 7 & 35 & 5 \\
\hline 6 & 4 & 5 & 2 & 2 & 3 & 5 & 4 & 2 & 27 & 2 \\
\hline 7 & 1 & 1 & 1 & 1 & 1 & 1 & 1 & 1 & 8 & 1 \\
\hline
\end{tabular}

Source: own

criteria. Using methods of mathematical statistics the consistency of expert judgements is determined. The results of expert ranking are given in Table 5.

On a basis of the results of criteria ranking it is verified if the expert judgements are consistent. The level of consistency is defined by the concordance coefficient of $\mathrm{M}$. Kendall (Kendall, 1970; Podvezko, 2007; Podvezko \& Sivilevicius, 2013).

If expert estimates (data of Tab. 5) are marked as $e_{i k}$, the sum of ranks of each index as $e_{i}=\sum_{k=1}^{r} e_{i k}$, their average as $\bar{e}=\frac{\sum_{i=1}^{m} e_{i}}{m}$ $(i=1,2, \ldots, m ; k=1,2, \ldots, r ;$ where $m$ - the number of criteria used, $r$ - the number of experts), the concordance coefficient $W$ is calculated by the formula (Kendall, 1970):

$$
W=\frac{12 S}{r^{2} m\left(m^{2}-1\right)},
$$

The sum of squares of deviation from the total average of values $S$ is defined by the formula:

$$
S=\sum_{i=1}^{m}\left(e_{i}-\bar{e}\right)^{2}
$$

The level of consistency of expert estimates is defined not by the concordance coefficient $W$ itself but by the related criterion $x^{2}$ calculated by the formula (Kendall, 1970):

$$
x^{2}=W r(m-1)=\frac{12 S}{r m(m+1)},
$$

It has been proven (Kendall, 1970) that if calculated by the formula (5) the value of $x^{2}$ is higher than the critical $x_{k r}^{2}$ taken from the distribution table of $x^{2}$ with $v \stackrel{k r}{=} m-1$ degree of freedom and the selected significance level $\alpha$ close to zero, a statistical hypothesis on the consistency of expert estimates is assumed.

Based on table 5 the calculated concordance coefficient $W=0.597$. Based on formula (5) the calculated $x^{2}=28.66$ value exceeds the critical value $x_{k r}^{2}=12.59$ with the significance level $\alpha=0.05$ and the freedom degree $v=7-1=6$. This shows that the expert estimates are consistent.

In the second stage the experts directly assessed (in percent) the significance of each criterion $c_{i k}\left(\sum_{i=1}^{m} c_{i k}=100 ; k=1,2, \ldots, r\right)$. The estimates make it possible to calculate the weights of criteria $\omega_{i}$ as the average of all estimates by the formula:

$$
\omega_{i}=\sum_{k=1}^{r} c_{i k} /(100 r), \quad(i=1,2, \ldots, m),
$$

The expert estimates of criteria significance and criteria weights are given in Table 7 .

When estimating criteria significance the criteria comparison matrix was developed using AHP (Analytic Hierarchy Process) method (Saaty, 2005; Saaty, 1980; Podvezko, 2009; Kutut et al., 2014), (Tab. 6). 


Tab. 6: The criteria comparison matrix of all experts using AHP method
\begin{tabular}{c|c|c|c|c|c|c|c} 
& $\mathbf{1}$ & $\mathbf{2}$ & $\mathbf{3}$ & $\mathbf{4}$ & $\mathbf{5}$ & $\mathbf{6}$ & $\mathbf{7}$ \\
\hline $\mathbf{1}$ & 1 & 3 & $1 / 3$ & 4 & 2 & $1 / 3$ & $1 / 4$ \\
\hline $\mathbf{2}$ & $1 / 3$ & 1 & $1 / 6$ & 1 & $1 / 2$ & $1 / 3$ & $1 / 7$ \\
\hline $\mathbf{3}$ & 3 & 6 & 1 & 5 & 4 & 2 & $1 / 2$ \\
\hline $\mathbf{4}$ & $1 / 4$ & 1 & $1 / 5$ & 1 & $1 / 2$ & $1 / 4$ & $1 / 6$ \\
\hline $\mathbf{5}$ & $1 / 2$ & 2 & $1 / 4$ & 2 & 1 & $1 / 2$ & $1 / 5$ \\
\hline $\mathbf{6}$ & 3 & 5 & $1 / 2$ & 4 & 2 & 1 & $1 / 3$ \\
\hline $\mathbf{7}$ & 4 & 7 & 2 & 6 & 5 & 3 & 1 \\
\hline
\end{tabular}

Source: own

Tab. 7: The direct expert estimates of criteria significance and criteria weights

\begin{tabular}{|c|c|c|c|c|c|c|c|c|c|c|c|}
\hline \multirow{2}{*}{$m$} & \multicolumn{8}{|c|}{ Experts } & \multirow{2}{*}{$\begin{array}{c}\text { Sum of } \\
\text { estimates }\end{array}$} & \multirow{2}{*}{ Weights } & \multirow{2}{*}{ Position } \\
\hline & $r_{1}$ & $r_{2}$ & $r_{3}$ & $r_{4}$ & $r_{5}$ & $r_{6}$ & $r_{7}$ & $r_{8}$ & & & \\
\hline 1 & 21 & 24 & 10 & 15 & 5 & 15 & 15 & 5 & 110 & 0.1375 & 4 \\
\hline 2 & 11 & 5 & 6 & 13 & 1 & 8 & 5 & 10 & 59 & 0.0738 & $6-7$ \\
\hline 3 & 18 & 15 & 20 & 10 & 20 & 12 & 20 & 10 & 125 & 0.1562 & 2 \\
\hline 4 & 4 & 4 & 12 & 12 & 2 & 5 & 5 & 15 & 59 & 0.0738 & $6-7$ \\
\hline 5 & 7 & 16 & 12 & 15 & 2 & 20 & 10 & 5 & 87 & 0.1088 & 5 \\
\hline 6 & 14 & 10 & 20 & 15 & 20 & 10 & 15 & 20 & 124 & 0.1550 & 3 \\
\hline 7 & 25 & 26 & 20 & 20 & 50 & 30 & 30 & 35 & 236 & 0.2950 & 1 \\
\hline
\end{tabular}

Source: own

The consistency index of the expert pairwise comparison C.I. $=0.036$, the consistency ratio C.R. $=0.027<0.1$, i.e. the estimates are consistent.

To reduce the impact of randomness on the determination of weights the same experts once again filled in the criteria comparison matrix by AHP method. The weights, calculated by two AHP methods, are given in Tab. 8 and Fig 7 . They also give weights of direct estimates and the mean of weights.

\subsection{Evaluation of the Occupancy Potential for the Parking Lots}

When analyzing the occupancy potential for the parking lots the world-widely used SAW, TOPSIS and PROMETHEE methods were applied reflecting the main ideas of these methods. A bibliography of only two methods PROMETHEE and TOPSIS is made of several hundred publications each, the methods were used in many various fields - from logistics to health protection (Behzadian et al., 2010; Behzadian et al., 2012; Mardani et al., 2015a; Mardani et al., 2015b). The simplest SAW (Simple Additive Weighting) method (Hwang \& Yoon, 1981; Podvezko, 2011; Tupenaite et al., 2010; Bagocius et al., 2014) reflects the idea of qualitative MCDM methods - integration of the values of indices and their weights into one quantity - criterion of the method. In this case, the sum of the weighted normalized values of all criteria is calculated for each $j$-th parking lot. The criterion of the method $S_{j}$ is calculated by the formula:

$$
S_{j}=\sum_{i=1}^{m} \omega_{i} \tilde{r}_{i j},
$$

where $\omega_{i}$ is weight of the $i$-th criterion, $\tilde{r}_{i j}$ is the normalized value of $i$-th criterion for $j$-th parking lot. 


\section{Tab. 8: Criteria weights calculated by different methods}

\begin{tabular}{l|c|c|c|c|c|c|c} 
& $\mathbf{1}$ & $\mathbf{2}$ & $\mathbf{3}$ & $\mathbf{4}$ & $\mathbf{5}$ & $\mathbf{6}$ & $\mathbf{7}$ \\
\hline AHP (1) & 0.1020 & 0.0402 & 0.2414 & 0.0395 & 0.0674 & 0.1543 & 0.3553 \\
\hline AHP (2) & 0.0944 & 0.0440 & 0.2200 & 0.0457 & 0.0512 & 0.1594 & 0.3853 \\
\hline Direct & 0.1375 & 0.0738 & 0.1563 & 0.0738 & 0.1088 & 0.1550 & 0.2950 \\
\hline The mean of weights & 0.1113 & 0.0527 & 0.2058 & 0.0531 & 0.0759 & 0.1562 & 0.3452 \\
\hline Location & $\mathbf{4}$ & $\mathbf{7}$ & $\mathbf{2}$ & $\mathbf{6}$ & $\mathbf{5}$ & $\mathbf{3}$ & $\mathbf{1}$ \\
\hline
\end{tabular}

Source: own

\section{Fig. 7: The average of criteria significance of the parking lots of shopping centres}

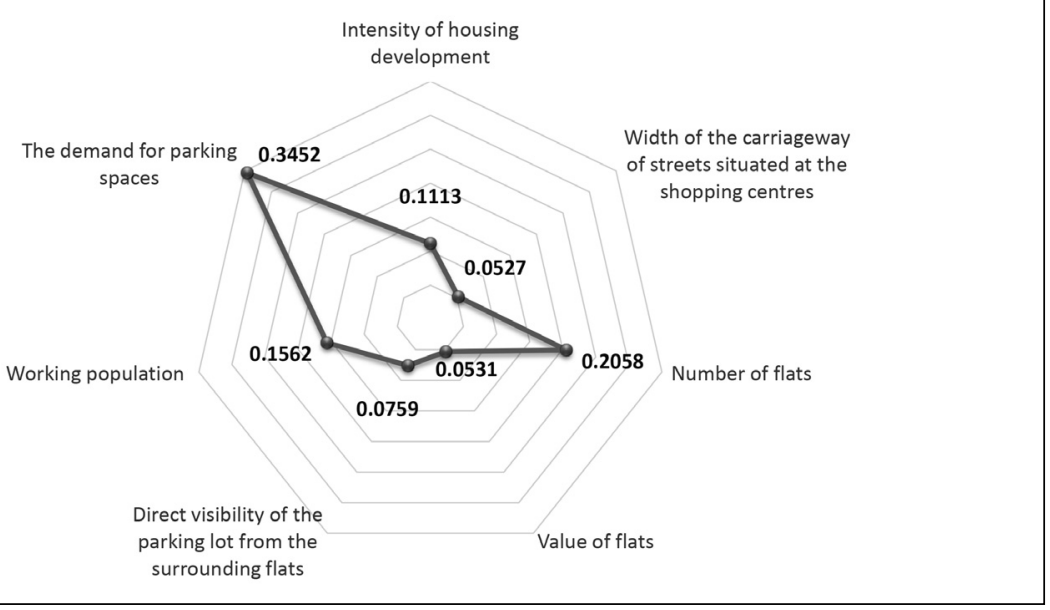

Source: own

The SAW method was used the "classical" normalization where the normalized values $\tilde{r}_{i j}$ are calculated by the formula:

$$
\tilde{r}_{i j}=\frac{r_{i j}}{\sum_{j=1}^{n} r_{i j}},
$$

where $r_{i j}$ is the value of $i$-th criterion for $j$-th parking lot taken from the table of expert estimates.

The main principle of TOPSIS (Technique for Order Preference by Similarity to an Ideal Solution) method is that from compared alternatives the chosen one will have the shortest distance from the best solutions and the largest distance from the worst solutions (Hwang \& Yoon, 1981; Opricovic \& Tzeng, 2004; Ginevicius et al., 2012).
The TOPSIS method uses vector normalisation:

$$
\tilde{r}_{i j}=\frac{r_{i j}}{\sqrt{\sum_{j=1}^{n} r_{i j}^{2}}} i=1, \ldots, m ; j=1, \ldots n .
$$

The best solution (alternative) $V^{*}$ and the worst solution $V^{-}$are calculated by the formulas:

$$
\begin{aligned}
& V^{*}=\left\{V_{1}^{*}, V_{2}^{*}, \ldots, V_{m}^{*}\right\}=\left\{\left(\max _{j} \omega_{i} r_{i j} / i \in I_{1}\right),\right. \\
& \left.\left(\min _{j} \omega_{i} \tilde{r}_{i j} / i \in I_{2}\right)\right\}, \\
& V^{-}=\left\{V_{1}^{-}, V_{2}^{-}, \ldots, V_{m}^{-}\right\}=\left\{\left(\min _{j} \omega_{i} r_{i j} / i \in I_{1}\right),\right. \\
& \left.\left(\max _{j} \omega_{i} \tilde{r}_{i j} / i \in I_{2}\right)\right\},
\end{aligned}
$$

where $I_{1}-$ a set of numbers of maximizing 
criteria, $I_{2}-$ a set of numbers of minimizing criteria, $\omega_{i}$ is the weight of $i$-th criterion $\left(\sum_{i=1}^{m} \omega_{i}=1\right)$.

The total distance of each compared alternative to the best solutions $D_{i}^{*}$ and to the worst solutions $D_{j}^{-}$is calculated by the formulas:

$$
\begin{aligned}
& D_{j}{ }^{*}=\sqrt{\sum_{i=1}^{m}\left(\omega_{i} \tilde{r}_{i j}-V_{i}^{*}\right)^{2}}, \\
& D_{j}^{-}=\sqrt{\sum_{i=1}^{m}\left(\omega_{i} \tilde{r}_{i j}-V_{i}^{-}\right)^{2}},
\end{aligned}
$$

The criterion of the TOPSIS method $C_{j}^{*}$ is calculated by the formula:

$$
C_{j}^{*}=\frac{D^{-}}{D_{j}^{*}+D_{j}^{-}}(j=1, \ldots, n)\left(0 \leq C_{j}^{*} \leq 1\right),
$$

\section{PROMETHEE (Preference Ranking} Organisation Method for Enrichment Evaluation) method (Brans \& Mareschal, 2005; Podvezko \& Podviezko, 2010a; Podvezko \& Podviezko, $2010 \mathrm{~b}$ ) instead of normalized values uses the values of so-called preference function $p(d)$ where the argument $d$ is the difference between the index values of two compared alternatives, i.e. distance between them. This function depends on two parameters - the indifference limit $q$ and the preference limit s.

PROMETHEE methods compare all the $A_{j}$ and $A_{k}$ alternatives by calculating the outranking relation $\pi\left(A_{j}, A_{k}\right)$.
The outranking relation $\pi\left(A_{j}, A_{k}\right)$ is calculated by the formula:

$$
\Pi\left(A_{j}, A_{k}\right)=\sum_{i=1}^{m} \omega_{i} p_{t}\left(d_{i}\left(A_{j}, A_{k}\right)\right),
$$

where $\omega_{i}$ is the weight (significance) of i-th criterion $R_{i} ; d_{i}\left(A_{j}, A_{k}\right)=r_{i j}-r_{i k}-$ the difference between the values $r_{i j}$ and $r_{i k}$ of $\mathrm{i}$-th criterion $R_{i}$ of alternatives $A_{j}$ and $A_{k} ; p_{t}(d)=p_{t}\left(d_{i}\left(A_{j}, A_{k}\right)\right)$ - $\mathrm{t}$-th preference function selected for $\mathrm{i}$-th criterion.

PROMETHEE methods assess the sums of all "outcoming" relations for each $\mathrm{j}$-th alternative:

$$
F_{j}^{+}=\sum_{k=1}^{n} \pi\left(A_{j}, A_{k}\right),
$$

and the sums of all "incoming" relations:

$$
F_{j}^{-}=\sum_{k=1}^{n} \pi\left(A_{k}, A_{j}\right), \quad(\mathrm{j}=1,2, \ldots, \mathrm{n}),
$$

The method PROMETHEE II calculates differences $F_{j}=F_{j}^{+}-F_{j}^{-}$between the relations of $F_{j}^{+}$and $F_{j}^{j}$ and ranks the alternatives in a descending order of the differences between their values $F_{j}$.

From the preference functions $p(d)$, most frequently used in practice, in this research the authors chose the so-called V-shape function best suitable to all criteria (Fig. 8).

The study parking lots were divided by their occupancy into four groups. Tables 1-4 give the values of all criteria.

The values of evaluation criteria obtained for all parking lots in each group using the

\section{Fig. 8: V-shape with indifference preference function}

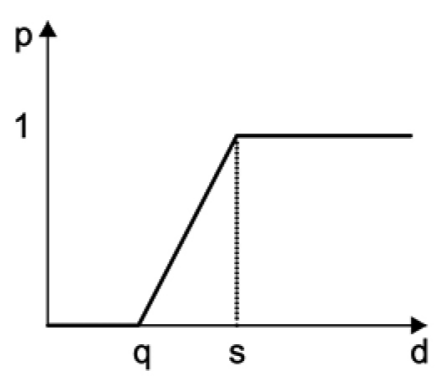

$$
p(d)=\left\{\begin{array}{l}
0, \text { when } \mathrm{d} \leq \mathrm{q} \\
\frac{\mathrm{d}-\mathrm{q}}{\mathrm{s}-\mathrm{q}}, \text { when } \mathrm{q}<\mathrm{d} \leq \mathrm{s} \\
1, \text { when } \mathrm{d}>\mathrm{s}
\end{array}\right.
$$




\begin{tabular}{|c|c|c|c|c|c|c|c|c|c|c|}
\hline \multirow{4}{*}{$\begin{array}{l}\text { No. of the } \\
\text { parking } \\
\text { lot of } \\
\text { shopping } \\
\text { centre }\end{array}$} & \multicolumn{10}{|c|}{$\begin{array}{l}\text { Results of the evaluation of parking lots of group I by SAW, TOPSIS } \\
\text { and PROMETHEE methods }\end{array}$} \\
\hline & \multicolumn{8}{|c|}{ Method } & \multirow{3}{*}{$\begin{array}{l}\text { Sum of } \\
\text { positions }\end{array}$} & \multirow{3}{*}{ Position } \\
\hline & \multicolumn{2}{|c|}{ SAW } & \multicolumn{2}{|c|}{ TOPSIS } & \multicolumn{4}{|c|}{ PROMETHEE } & & \\
\hline & $S_{j}$ & Position & $C_{j}^{*}$ & Position & $\boldsymbol{F}_{j}^{+}$ & $F_{j}^{-}$ & $F_{j}$ & Position & & \\
\hline 1 & 0.1270 & 4 & 0.4014 & 5 & 1.170 & 1.479 & -0.309 & 4 & 13 & 4 \\
\hline 2 & 0.1467 & 2 & 0.6356 & 2 & 2.346 & 0.875 & 1.471 & 2 & 6 & 2 \\
\hline 3 & 0.0983 & 8 & 0.2699 & 8 & 0.480 & 2.176 & -1.696 & 8 & 24 & 8 \\
\hline 4 & 0.1309 & 3 & 0.4398 & 4 & 1.362 & 1.541 & -0.179 & 3 & 10 & 3 \\
\hline 5 & 0.1540 & 1 & 0.7322 & 1 & 2.610 & 0.396 & 2.214 & 1 & 3 & 1 \\
\hline 6 & 0.1066 & 7 & 0.4608 & 3 & 1.748 & 2.266 & -0.518 & 6 & 16 & 5 \\
\hline 7 & 0.1166 & 6 & 0.3911 & $6-7$ & 1.198 & 1.548 & -0.350 & 5 & 17.5 & 6 \\
\hline 8 & 0.1202 & 5 & 0.3911 & $6-7$ & 0.951 & 1.583 & -0.632 & 7 & 18.5 & 7 \\
\hline
\end{tabular}

Source: own

\begin{tabular}{|c|c|c|c|c|c|c|c|c|c|c|}
\hline \multirow{4}{*}{$\begin{array}{c}\text { Tab. 10: } \\
\text { No. of the } \\
\text { parking } \\
\text { lot of } \\
\text { shopping } \\
\text { centre } \\
\end{array}$} & \multicolumn{10}{|c|}{$\begin{array}{l}\text { Results of the evaluation of parking lots of group II by SAW, TOPSIS } \\
\text { and PROMETHEE methods }\end{array}$} \\
\hline & \multicolumn{8}{|c|}{ Method } & \multirow{3}{*}{$\begin{array}{l}\text { Sum of } \\
\text { positions }\end{array}$} & \multirow{3}{*}{ Position } \\
\hline & \multicolumn{2}{|c|}{ SAW } & \multicolumn{2}{|c|}{ TOPSIS } & \multicolumn{4}{|c|}{ PROMETHEE } & & \\
\hline & $S_{j}$ & Position & $C_{j}^{*}$ & Position & $F_{j}^{+}$ & $F_{j}^{-}$ & $F_{j}$ & Position & & \\
\hline 1 & 0.1493 & 3 & 0.5063 & 2 & 1.988 & 0.963 & 1.035 & 3 & 8 & 3 \\
\hline 2 & 0.1303 & 4 & 0.4065 & 4 & 1.508 & 1.911 & -0.402 & 6 & 14 & $4-5$ \\
\hline 3 & 0.1262 & 5 & 0.3886 & 5 & 1.848 & 1.118 & 0.730 & 4 & 14 & $4-5$ \\
\hline 4 & 0.1058 & 6 & 0.3003 & 6 & 1.256 & 1.376 & -0.120 & 5 & 17 & 6 \\
\hline 5 & 0.1560 & 2 & 0.4834 & 3 & 2.572 & 0.456 & 2.115 & 1 & 6 & 2 \\
\hline 6 & 0.0418 & 8 & 0 & 8 & 0 & 4.309 & -4.309 & 8 & 24 & 8 \\
\hline 7 & 0.1939 & 1 & 0.7262 & 1 & 3.316 & 1.271 & 2.045 & 2 & 4 & 1 \\
\hline 8 & 0.0963 & 7 & 0.2709 & 7 & 1.169 & 2.265 & -1.094 & 7 & 21 & 7 \\
\hline
\end{tabular}

Source: own

SAW, TOPSIS and PROMETHEE methods, the corresponding positions, the sum of positions and the summary of evaluation (ranking) are given Tables 9-12.

Calculations, made by the above multiplecriteria methods, show that the best evaluation results in group I of parking lots are represented by the parking lot of the shopping centre No. 5 (Tab. 9). This is determined by the intensity of housing development (1.08), large number of flats $(1,720), 2,470$ working population and its location within a 300 metre radius of the shopping centre (Tab. 1). The lot is situated within $18 \%$ visibility zone from the neighbouring residential houses, provided with convenient entrance and with fast accessibility from the parking lot to the houses.

The most unfavourable situation is represented by the parking lots of the shopping centres No. 7 and 8 (Tab. 9). This is explained by the lower demand for parking spaces, less flats and less residents (Tab. 1). In the parking lots of shopping centres with the occupancy of 51 to $75 \%$ (group II) the best evaluation results were showed by the parking lots at the shopping centres No. 5 and 7 (Tab. 10). This area has a high intensity of housing development $0.96-1.03$, respectively, the number of flats 


\begin{tabular}{|c|c|c|c|c|c|c|c|c|c|c|}
\hline \multirow{4}{*}{$\begin{array}{l}\text { Tab. 11: } \\
\text { No. of the } \\
\text { parking } \\
\text { lot of } \\
\text { shopping } \\
\text { centre }\end{array}$} & \multicolumn{10}{|c|}{$\begin{array}{l}\text { Results of the evaluation of parking lots of group III by SAW, TOPSIS } \\
\text { and PROMETHEE methods }\end{array}$} \\
\hline & \multicolumn{8}{|c|}{ Method } & \multirow{3}{*}{$\begin{array}{c}\text { Sum of } \\
\text { positions }\end{array}$} & \multirow{3}{*}{ Position } \\
\hline & \multicolumn{2}{|c|}{ SAW } & \multicolumn{2}{|c|}{ TOPSIS } & \multicolumn{4}{|c|}{ PROMETHEE } & & \\
\hline & $S_{j}$ & Position & $C_{j}^{*}$ & Position & $F_{j}^{+}$ & $F_{j}^{-}$ & $F_{j}$ & Position & & \\
\hline 1 & 0.0539 & 13 & 0.2198 & 13 & 0.252 & 3.455 & -3.203 & 13 & 39 & 13 \\
\hline 2 & 0.0841 & 4 & 0.5624 & 2 & 2.495 & 2.555 & -0.060 & 8 & 14 & $4-5$ \\
\hline 3 & 0.0614 & 11 & 0.2795 & 12 & 1.973 & 3.192 & -1.219 & 10 & 33 & 11 \\
\hline 4 & 0.0790 & 8 & 0.4632 & 7 & 2.893 & 1.440 & 1.453 & 4 & 19 & 7 \\
\hline 5 & 0.0761 & 9 & 0.3616 & 10 & 1.895 & 2.430 & -0.534 & 9 & 28 & 9 \\
\hline 6 & 0.0805 & 6 & 0.4172 & 8 & 3.211 & 3.164 & 0.047 & 7 & 21 & 8 \\
\hline 7 & 0.0872 & 2 & 0.5276 & 4 & 3.534 & 1.213 & 2.231 & 1 & 7 & 2 \\
\hline 8 & 0.0563 & 12 & 0.3306 & 11 & 1.657 & 3.375 & -1.718 & 11 & 34 & 12 \\
\hline 9 & 0.0853 & 3 & 0.5440 & 3 & 2.456 & 1.516 & 0.940 & 5 & 11 & 3 \\
\hline 10 & 0.0799 & 7 & 0.5258 & 5 & 3.036 & 2.154 & 0.882 & 6 & 18 & 6 \\
\hline 11 & 0.0652 & 10 & 0.4098 & 9 & 1.725 & 4.366 & -2.641 & 12 & 31 & 10 \\
\hline 12 & 0.0828 & 5 & 0.4719 & 6 & 2.884 & 1.233 & 1.651 & 3 & 14 & $4-5$ \\
\hline 13 & 0.1085 & 1 & 0.6165 & 1 & 3.941 & 1.859 & 2.082 & 2 & 4 & 1 \\
\hline
\end{tabular}

Source: own

$-1,640-1,760$, respectively and the number of working residents $-1,750-2,310$, respectively. Visibility from the residential houses to the parking lots comes to $9-11 \%$ (Tab. 2).

A low occupancy (26-50\%) and inefficient use of the parking lots of group III is determined by the adjacent streets (of categories A, B and $C$ ) of high traffic volume, inconvenient accessibility, a low visibility of parking lots from the residential houses. In this group the relatively best evaluation results were obtained for the parking lots of the shopping centres No. 7 and 13 (Tab. 11). The intensity of housing development is $0.35-0.43$, respectively, the number of flats $680-730$, respectively, the number of working population is 630-970, respectively (Tab. 3).

In group IV of the parking lots with the lowest occupancy (up to $25 \%$ ) the evaluation results are similar to those of group III, however, the parking lots of those shopping centres are distinguished by especially large number of parking spaces (400-500), a complicated accessibility, paid parking at night (Tab. 12). A low occupancy of parking lots in winter is determined by a small number of flats (580), a small number of working population (590), a low intensity of housing development (0.29) and the streets of high traffic volume (Tab. 4).

\subsection{The Eeffective Use and Development of the Parking Lots of Shopping Centres}

The use of multiple-criteria methods SAW, TOPSIS and PROMETHEE showed that the occupancy of the parking lots of shopping centres in urbanized areas is mostly influenced by the demand for parking spaces, intensity of housing development, the number of flats and working population, accessibility of parking lots and their direct visibility from residential houses. The implemented complex analysis enabled to identify four groups of shopping centres by the occupancy of their parking lots.

The main criteria were determined based on which the development of shopping centres in the urbanized areas shall be planned at the streets of certain categories taking into consideration the urban transport system.

The group I represents not large shopping centres (Fig. 9) having up to 100 parking spaces. Those shopping centres are located in residential districts, within the territory of multi-storey houses, where the prevailing intensity of housing development is higher than 1.00 . In the adjacent area, at a $300 \mathrm{~m}$ radius from the shopping centre parking lot the demand for parking spaces 


\begin{tabular}{|c|c|c|c|c|c|c|c|c|c|c|}
\hline \multirow{4}{*}{$\begin{array}{l}\text { No. of the } \\
\text { parking } \\
\text { lot of } \\
\text { shopping } \\
\text { centre }\end{array}$} & \multicolumn{10}{|c|}{$\begin{array}{l}\text { Results of the evaluation of parking lots of group IV by SAW, TOPSIS } \\
\text { and PROMETHEE methods }\end{array}$} \\
\hline & \multicolumn{8}{|c|}{ Method } & \multirow{3}{*}{$\begin{array}{c}\text { Sum of } \\
\text { positions }\end{array}$} & \multirow{3}{*}{ Position } \\
\hline & \multicolumn{2}{|c|}{ SAW } & \multicolumn{2}{|c|}{ TOPSIS } & \multicolumn{4}{|c|}{ PROMETHEE } & & \\
\hline & $S_{j}$ & Position & $C_{j}^{*}$ & Position & $F_{j}^{+}$ & $F_{j}^{-}$ & $F_{j}$ & Position & & \\
\hline 1 & 0.0501 & 13 & 0.4336 & 7 & 2.381 & 2.942 & -0.561 & 13 & 33 & 12 \\
\hline 2 & 0.0532 & 10 & 0.3352 & 13 & 4.340 & 3.277 & 1.062 & 9 & 32 & 11 \\
\hline 3 & 0.0645 & 3 & 0.4674 & 3 & 4.046 & 1.018 & 3.029 & 4 & 10 & 3 \\
\hline 4 & 0.0539 & 9 & 0.3904 & 10 & 2.525 & 1.420 & 1.035 & 10 & 29 & $9-10$ \\
\hline 5 & 0.0548 & 8 & 0.4329 & 8 & 2.724 & 2.285 & 0.438 & 12 & 28 & 8 \\
\hline 6 & 0.0334 & 16 & 0.1849 & 19 & 0.934 & 4.821 & -3.887 & 18 & 53 & 18 \\
\hline 7 & 0.0624 & 4 & 0.4060 & 9 & 4.000 & 2.893 & 1.107 & 8 & 21 & 7 \\
\hline 8 & 0.0312 & 17 & 0.1908 & 18 & 0.370 & 4.554 & -4.184 & 19 & 54 & 19 \\
\hline 9 & 0.0456 & 14 & 0.2868 & 17 & 2.264 & 4.584 & -2.320 & 15 & 46 & $14-15$ \\
\hline 10 & 0.0587 & 6 & 0.4605 & 6 & 2.965 & 1.459 & 1.506 & 6 & 18 & $5-6$ \\
\hline 11 & 0.0770 & 1 & 0.6036 & 1 & 5.048 & 1.930 & 3.118 & 3 & 5 & 1 \\
\hline 12 & 0.0551 & 7 & 0.3865 & 17 & 3.845 & 1.451 & 2.394 & 5 & 29 & $9-10$ \\
\hline 13 & 0.0305 & 18 & 0.3189 & 14 & 2.122 & 4.840 & -2.718 & 16 & 48 & 16 \\
\hline 14 & 0.0502 & 12 & 0.3783 & 12 & 2.453 & 1.767 & 0.686 & 11 & 35 & 13 \\
\hline 15 & 0.0507 & 11 & 0.4625 & 5 & 6.431 & 3.113 & 3.318 & 2 & 18 & $5-6$ \\
\hline 16 & 0.0708 & 2 & 0.4637 & 4 & 5.214 & 1.067 & 4.147 & 1 & 7 & 2 \\
\hline 17 & 0.0290 & 20 & 0.2908 & 15 & 1.335 & 4.055 & -2.719 & 17 & 52 & 17 \\
\hline 18 & 0.0601 & 5 & 0.4894 & 2 & 3.146 & 1.644 & 1.502 & 7 & 14 & 4 \\
\hline 19 & 0.0424 & 15 & 0.2712 & 17 & 1.487 & 3.418 & -1.930 & 14 & 46 & $14-15$ \\
\hline 20 & 0.0236 & 19 & 0.1338 & 20 & 0.249 & 5.272 & -5.023 & 20 & 59 & 20 \\
\hline
\end{tabular}

Source: own

reaches on average $363 \%$, the average of working population living within the adjacent area $-2,022$, the average number of flats $-1,795$. The research has determined that accessibility of the parking lot of shopping centre from the residential house on foot varies from $3 \mathrm{~min}$ to $5 \mathrm{~min}$.

In order to reduce journey time, to reach optimization of engineering infrastructure and territorial development, those shopping centres shall be built in the territories of multi-storey houses. However, they must satisfy the main three limit values of criteria set by the experts (Tab. 13): intensity of housing development higher than 1.00 , the number of working residents - more than 2,000 and the number of flats more than 1,800 . Accessibility of the parking lot from the residential houses on foot shall not exceed $5 \mathrm{~min}$ and they cannot be separated by the street not larger than of category D (Fig. 9).
It was determined by research and substantiated by practical calculations that those shopping centres allow to reduce the number of parking spaces by $5.6 \%$ per one flat. For example, having built 100 parking lots this will help to save 0.2 ha of the total area of the territory and 0.43 thousand EUR.

The group II (Fig. 10) represents shopping centres having from 100 to 150 parking spaces. In the adjacent area of shopping centres the demand for parking spaces reaches on average $374 \%$, intensity of housing development - from 0.7 to 1.00 , the average of working population living within the adjacent area $-1,610$, the average number of flats $-1,428$. The research has determined that accessibility of the parking lot of shopping centre from the residential house on foot varies from $5 \mathrm{~min}$ to 7 minutes (Fig. 10). 
Fig. 9: The scheme of a parking lot of the shopping centres of group I

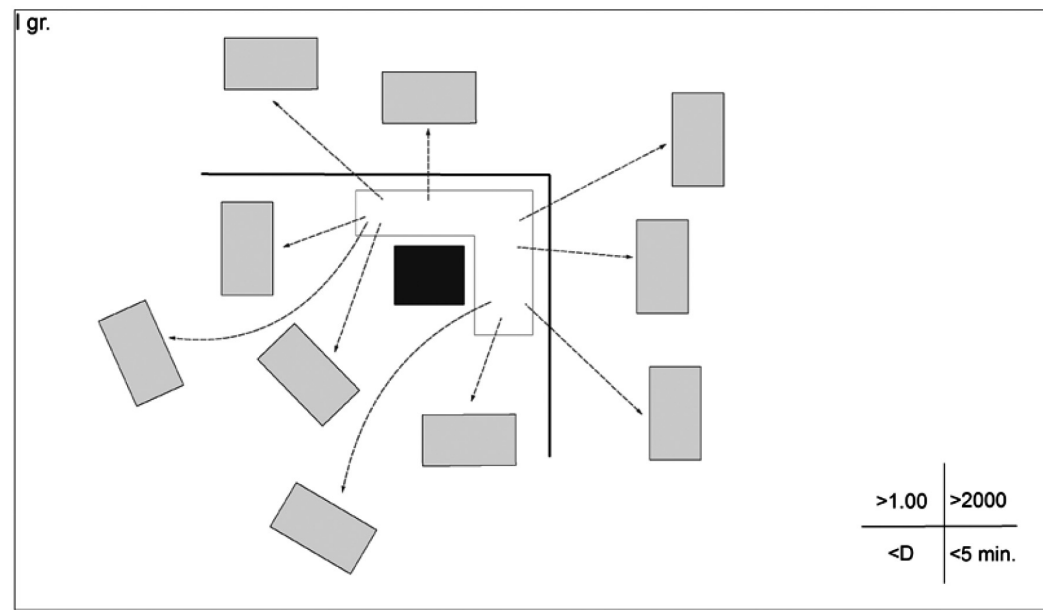

Legend

$\square$ Retail center $\square$ Retail center parking zone $\quad \cdots$ Walking route
$\square$ Building
Intensity of housing development Working population

Width of the carriageway of streets
situated at the shooping centres

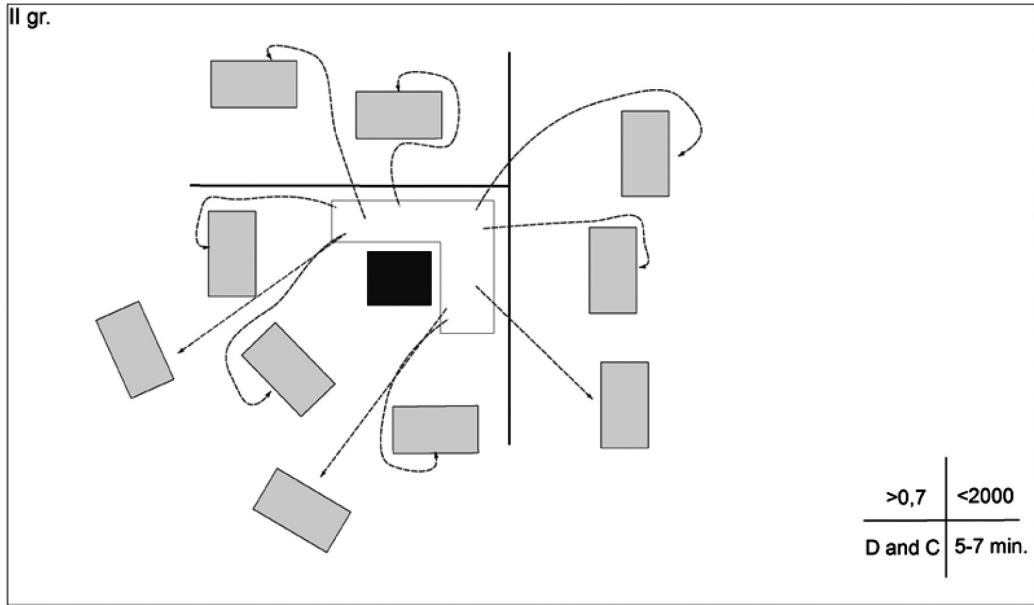

Legend

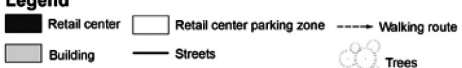

Intensity of housing development Working population

Width of the carriageway of streets
situated at the shopping centres 
Fig. 11: The scheme of a parking lot of the shopping centres of group III

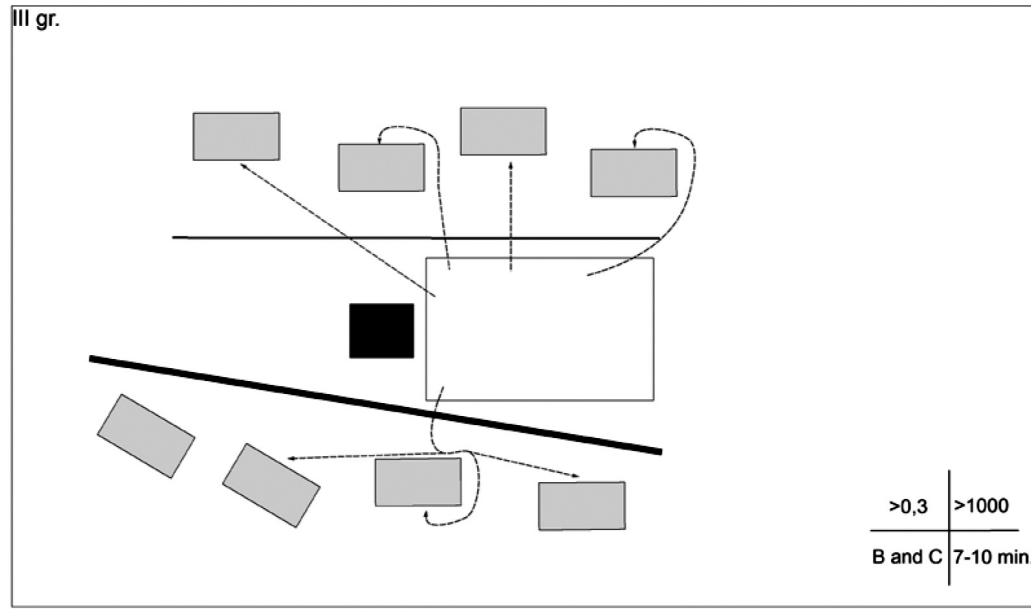

Legend

Retail center $\square$ Retail center parking zone $\rightarrow$ Walking route

Intensity of housing development Working population

$\square$ Building Streets

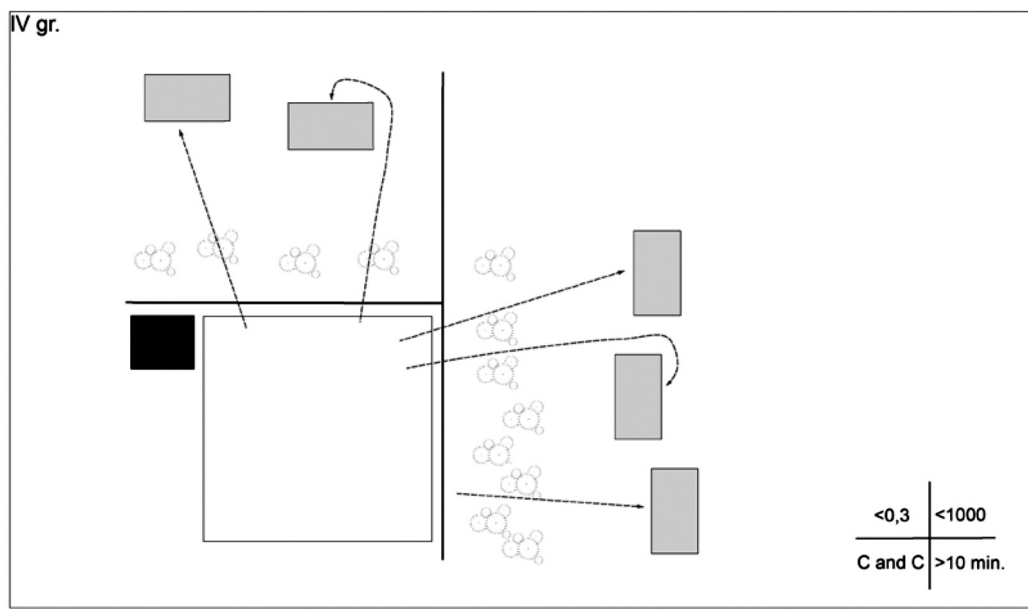


The parking lots occupy the total area of $2,000 \mathrm{~m}^{2}-3,000 \mathrm{~m}^{2}$, thus, it is necessary to find a ratio between the compact sustainable development, the shape of residential district and distribution of structural elements within the territory. Calculations have determined that at the given limit values (Tab. 13) those shopping centre parking lots allow to reduce the number of parking spaces by $5 \%$ per one flat.

The shopping centres of group III are located at the main urban transport corridors (the streets of category $\mathrm{B}$ or $\mathrm{C}$ ), therefore, research on their accessibility on foot showed that it will take the resident, having left his car in the parking of the shopping centre, from 7 to 10 minutes to come home. The parking lots occupy the total area of $3,000 m^{2}-4,000 m^{2}$, thus, due to their size they are not recommended in the residential areas of multi-storey houses. Accessibility of those shopping centres on foot is poor, usually they are separated by fast-speed streets, therefore, the drivers waste time to cross the street. Due to the above mentioned circumstances, it is recommended to build this type of shopping centres in the territory of mixed housing development since there is a good accessibility by car, a large variety of goods and services, free parking. Those parking lots are suggested to be used for Park\&Ride system. In a daytime the parking lots will be used by people working in this area and the drivers travelling to the city centre.

Group IV represents the largest shopping centres having more than 200 parking spaces and occupying the total area of more than $4,000 \mathrm{~m}^{2}$. In the adjacent area of shopping centres the demand for parking spaces reaches on average $411 \%$, intensity of housing development - up to 0.3 , the average of working population living within the adjacent area -950 , the average number of flats -776 .
Those shopping centres are characterized by the functions of business, entertainment and specific services oriented towards rich and middle-class people. Their location demonstrates their exclusiveness: large parking lots (Fig. 12), concentration of 2-4 traffic lanes and generated flows, high level of public transport development, etc. Though multi-storey houses or their groups get into the analysed $300 \mathrm{~m}$ radius, only few residents use those parking lots. Research on their accessibility on foot showed that it will take the resident, having left his car in the parking of the shopping centre, at least 10 minutes to come home. Those shopping centres are recommended to be built in sub-urban areas and to adapt them to the systems of combined journeys, for example, Park\&Ride or Bikes\&Ride.

For the newly planned shopping centres and their parking lots the limit values were determined (Tab. 13). They were determined based on the analysis that was made using multi-criteria evaluation methods. Development of the parking lots $f$ shopping centre is regulated by four potential ways to reduce the demand for parking spaces. $P C_{p}$ - the total area of the shopping centre $\left(\mathrm{m}^{2}\right), P C_{\mathrm{v}}$ - number of parking spaces at the shopping centre, $U I$ - intensity of housing development, $D G_{s}-$ number of working residents, $B_{\mathrm{s}}-$ number of flats, $P C_{k}-$ occupancy coefficient for the parking lot based on the research findings, $P C_{r}$ - the suggested percentage of reducing the number of parking spaces per one flat.

\section{Conclusions}

It was determined that the occupancy index of the shopping centre parking lots from 10 p.m. to 2 a.m. varies from $1 \%$ to $100 \%$, and the average total occupancy index is $27 \%$. This means, that when planning the shopping centre parking lots

Tab. 13: The 4th shopping centres limit value

\begin{tabular}{|c|c|c|c|c|c|c|}
\hline \multirow{2}{*}{$P C_{p}, m^{2}$} & \multirow{2}{*}{$P C_{v}$} & \multicolumn{3}{|c|}{ Limit value } & \multirow{2}{*}{$P C_{k}$} & \multirow{2}{*}{$P C_{,}, \%$} \\
\hline & & UI & $D G_{s}$ & $B_{s}$ & & \\
\hline$\sim 2,000$ & $\sim 100$ & $>1.00$ & $>2,000$ & $>1,800$ & 1.00 & 5.6 \\
\hline $2,001-3,000$ & $101-150$ & $0.7-1.00$ & $1,500-1,999$ & $1,300-1,799$ & 0.60 & 5.0 \\
\hline $3,001-4,000$ & $151-200$ & $0.3-0.7$ & $1,200-1,499$ & $1,000-1,299$ & 0.40 & - \\
\hline$>4,001$ & $>201$ & $<0.3$ & $1,000-1,199$ & 800-999 & 0.12 & - \\
\hline
\end{tabular}


in the residential districts of multi-storey houses the existing housing development is not taken into consideration and no efforts are made to rationally use land plots for parking of cars. Therefore, the entirety of criteria of shopping centre parking lots was formed, which allowed to determine factors enabling to increase the occupancy index.

In order to improve parking conditions in the residential districts the list of 7 criteria was made. With the help of multi-criteria evaluation methods the significance and priority order of separate criteria were identified. The largest influence for the occupancy of shopping centres is made by the demand for parking spaces (0.3452), the number of flats $(0.2058)$ and the number of working residents in the residential district (0.1562).

Having divided the shopping centre parking lots into 4 groups based on the occupancy index of parking lots and having made the multicriteria evaluation analysis, the limit values for all the groups were obtained. The best results were obtained for the shopping centre parking lots of group I having up to 100 parking spaces allowing to more rationally use land plots for the parking of cars. However, in order to reach this, the obtained limit values must be as follows: intensity of housing development - at least 1.00 , the number of working residents at least 2,000, the number of flats - at least 1,800 . Calculations showed that the occupancy coefficient of parking lots can be increased to 1.00 . The second position is taken by the shopping centre parking lots of group II. When planning the shopping centres of this group in the residential districts of multi-storey houses a rational ratio shall be found between the shape of housing and the distribution of the structural elements of the parking lot of shopping centre within the territory.

\section{References}

Bagocius, V., Zavadskas, E. K., \& Turskis, Z. (2014) Selecting a location for a liquefied natural gas terminal in the eastern Baltic sea. Transport, 29(1), 69-74. doi:10.3846/16484142 .2014.897996.

Behzadian, M., Kazemzadeh, R. B., Albadvi, A., \& Aghdasi, M. (2010). PROMETHEE: A comprehensive literature review on methodologies and applications. European Journal of Operational Research, 200(1), 198-215. doi:10.1016/j.ejor.2009.01.021.
Behzadian, M., Otaghsara, S. K., Yazdani, M., \& Ignatius, J. (2012). A state-of the-art survey TOPSIS applicationas. Expert Systems with Applications. 39(17), 13051-13069. doi:10.1016/j.eswa.2012.05.056.

Brans, J.-P., \& Mareschal, B. (2005). PROMETHEE methods. In J. Figueira, S. Greco, \& M. Ehrgott (Eds.), Multiple Criteria Decision Analysis: State of the Art Surveys (pp. 163-195). Springer.

Burinskiene, M., \& Munch, H. (2003). Traffic development in Lithuania and East Germany (The Former GDR) in the past twenty years. Urbanistika ir Architektura, 17, 3-10.

Crawford, J. H. (2000). Carfree cities. Utrecht; Charlbury: International Books. Jon Carpenter distributor.

Czerwinski, S. (2013). System park and ride we Wrocławiu - przykład parkingu przy stadionie miejskim. Transport Miejski i Regionalny, 8, 10-18.

Ginevicius, R., Podvezko, V., Novotny, M., \& Komka, A. (2012) Comprehensive Quantitative Evaluation of the Strategic Potential of an Enterprise. Economic Computation and Economic Cybernetics Studies and Research, 46(1), 65-84.

Hole, A. R. (2004). Forecasting the demand for an employee Park and Ride service using commuters' stated choices. Transport Policy, 11(4), 355-362. doi:10.1016/j. tranpol.2004.04.003.

Hwang, C. L., \& Yoon, K. (1981). Multiple Attribute Decision Making. Methods and Applications A State-of-the-Art Survey. Berlin, Heidelberg, New York: Springer Verlag.

Jakimavičius, M., \& Burinskienè, M. (2010). Route planning methodology of an advanced traveller information system in Vilnius city. Transport, 25(2), 171-177. doi:10.3846/ transport.2010.21.

Kanajan, K., Kanajan, R., \& Kanajan, A. (2005). Projektirovanije magazinov i torgovych centrov. GI. 7. „Organizacija parkovki“. Moskva.

Kendall, M. (1970). Rank correlation methods. London: Griffin.

Kęsek, J. (2007). Parkingi podziemne w Krakowie. Zeszyty Naukowo-Techniczne Stowarzyszenia Inżynierów i Techników Komunikacji Rzeczpospolitej Polskiej Oddział w Krakowie. Materiały konferencyjne. 80(134), (pp. 75-94).

Kutut, V., Zavadskas, E. K., \& Lazauskas, M. (2014). Assessment of priority alternatives for 
preservation of historic buildings using model based on ARAS and AHP methods. Archives of Civil and Mechanical Engineering, 14(2), 287294. doi:10.1016/j.acme.2013.10.007.

Majdecka, J., Zwoliński, T., \& Niewitała, D. (2012). Przegląd rozwiązań dotyczących polityki parkingowej w miastach europejskich. Transport Miejski i Regionalny, 3, 2-22.

Mardani, A., Jusoh, A., Zavadskas, E. K., Cavallaro, F., \& Khalifah, Z. (2015a). Sustainable and Renewable Energy: An Overview of the Application of Multiple Criteria Decision Making Techniques and Approaches. Sustainability, 7(10), 13947-13984. doi:10.3390/su71013947.

Mardani, A., Jusoh, A., Zavadskas, E. K., Khalifah, Z., \& Nor, K. M. (2015b). Application of Multiple-Criteria Decision-Making Techniques and Approaches to Evaluating of Service Quality: A Systematic Review of the Literature. Journal of Business Economics and Management, 16(5), 1034-1068. doi:10.3846/1 6111699.2015.1095233.

Mingardo, G., \& Van Meerkerk, J. (2012). Is parking supply related to turnover of shopping areas? The case of the Netherlands. Journal of Retailing and Consumer Services, 19(2), 195201. doi:10.1016/j.jretconser.2011.12.001.

Opricovic, S., \& Tzeng, G. H. (2004). Compromise solution by MCDM methods: A comparative analysis of VIKON and TOPSIS. European Journal of Operational Research, 156(2), 445-455. doi:10.1016/S03772217(03)00020-1.

Palevičius, V., Paliulis, G. M., Venckauskaite, J., \& Vengrys, B. (2013). Evaluation of the requirement for passenger car parking spaces using multi-criteria methods. Journal of Civil Engineering and Management, 19(1), 49-58. doi:10.3846/13923730.2012.727463.

Parteka, T. (2010). Konstruktywna i destruktywna rola transportu w kształtowaniu treści i formy miast. Czasopismo Techniczne. Architektura, 107, 95-109.

Pech, A., Warmuth, G., Jens, K., \& Zeininger, J. (2009). Parkhäuser-Garagen: Grundlagen, Planung, Betrieb. New York: Springer. doi:10.1007/978-3-211-89239-8_9.

Petersen, A. (2009). Unbemerktes und einsames Sterben in Hamburg im Jahre 2008 (Doctoral dissertation, Med. Dissertation in Vorbereitung).

Pęski, S., \& Czechowski, F. (2001). Miejskie parkingi podziemne w Warszawie. Inżynieria i Budownictwo, 57(4), 203-206.
Podvezko, V. (2009). Application of AHP technique. Journal of Business Economics and Management, 10(2), 181-189. doi:10.3846/1611-1699.2009.10.181-189.

Podvezko, V. (2007). Determining the level of agreement of expert estimates. International Journal of Management and Decision Making, 8(5/6), 586-600. doi:10.1504/ IJMDM.2007.013420.

Podvezko, V. (2011). The Comparative Analysis of MCDA Methods SAW and COPRAS. Inžineriné Ekonomika-Engineering Economics, 22(2), 134-146.

Podvezko, V., \& Podviezko, A. (2010a). Dependence of multi-criteria evaluation result on choice of preference functions and their parameters. Technological and Economic Development of Economy, 16(1), 143-158. doi:10.3846/tede.2010.09.

Podvezko, V., \& Podviezko, A. (2010b). Use and choice of preference functions for evaluation of characteristics of socio-economical processes. In The $6^{\text {th }}$ International Scientific Conference Business and management'2010: selected papers. Vol. 2, May 13-14, 2010 Vilnius, Lithuania (pp. 1066-1071). Vilnius: Technika. doi:10.3846/bm.2010.143.

Podvezko, V., \& Sivilevicius, H. (2013). The use of AHP and rank correlation methods for determining the significance of the interaction between the elements of a transport system having a strong influence on traffic safety. Transport, 28(4), 389-403. doi:10.3846/164841 42.2013.866980.

Reimers, V. (2013). Convenience for the car-borne shopper: Are malls and shopping strips driving customers away? Transportation Research Part A: Policy and Practice, 49, 3547. doi:10.1016/j.tra.2013.01.002.

Saaty, T. L. (2005). The Analytic Hierarchy and Analytic Network Processes for the Measurement of Intangible Criteria and for Decision-Making. In J. Figueira, S. Greco, \& M. Ehrgott (Eds.), Multiple Criteria Decision Analysis: State of the Art Surveys (pp. 345408). Springer.

Saaty, T. L. (1980). The Analytic Hierarchy Process. New York: McGraw-Hill.

Szarata, A. (2007). Ocena efektywności funkcjonalnej systemu parkingów przesiadkowych (Park and Ride). Transport Miejski i Regionalny, 1, 29-35.

Teller, C. (2008). Shopping streets versus shopping malls-determinants of agglomeration 
format attractiveness from the consumers' point of view. The International Review of Retail, Distribution and Consumer Research, 18(4), 381-403. doi:10.1080/09593960802299452.

Tupenaite, L., Zavadskas, E. K., Kaklauskas, A., Turskis, Z., \& Seniut, M. (2010). Multiple Criteria Assessment of Alternatives for Built and Human Environment Renovation. Journal of Civil Engineering and Management, 16(2), 257-266. doi:10.3846/jcem.2010.30.

Wang, J. Y., Yang, H., \& Lindsey, R. (2004). Locating and pricing park-and-ride facilities in a linear monocentric city with deterministic mode choice. Transportation Research Part B: Methodological, 38(8), 709-731. doi:10.1016/j. trb.2003.10.002.

Zagorskas, J., \& Palevičius, V. (2011). Estimation of efficiency of retail centres car parking-lots. In D. Čygas, \& K. D. Froehner (Eds.), The 8th International Conference "Environmental Engineering": Selected papers, (pp. 1014-1017).

Assoc. Prof. Vytautas Palevičius, Ph.D. Vilnius Gediminas Technical University Faculty of Environmental Engineering Research institute of territorial planning vytautas.palevicius@vgtu.It
Prof. Marija Burinskienè, Ph.D.

Vilnius Gediminas Technical University Faculty of Environmental Engineering

Department of Urban Engineering marija.burinskiene@vgtu.It

Prof. Valentinas Podvezko, Ph.D. Faculty of Fundamental Sciences Department of Mathematical Statistics valentinas.podvezko@vgtu.It

Assoc. Prof. Gražvydas Mykolas Paliulis, Ph.D. Vilnius Gediminas Technical University Faculty of Environmental Engineering

Department of Urban Engineering msk@vgtu.It

Assoc. Prof. Edita Šarkienè, Ph.D. Vilnius Gediminas Technical University Faculty of Environmental Engineering

Department of Urban Engineering edita.sarkiene@vgtu.It

\section{Assoc. Prof. Jonas Šaparauskas, Ph.D.} Vilnius Gediminas Technical University Faculty of Civil Engineering Department of Construction Technology and Management jonas.saparauskas@vgtu.It 


\title{
Abstract
}

\section{RESEARCH ON THE DEMAND FOR PARKING LOTS OF SHOPPING CENTRES}

\author{
Vytautas Palevičius, Marija Burinskienè, Valentinas Podvezko, Gražvydas \\ Mykolas Paliulis, Edita Šarkienè, Jonas Šaparauskas
}

Over the last decade, in the cities of Lithuania the number of shopping centres has been increasingly growing, they were provided with large parking lots. The development of shopping centres has formed a new structural and very concentrated urban element the result of activity of which has not been widely studied from the transportation point of view. When implementing a sustainable urban development the authors of the article aimed at ensuring the effective use of the parking lots of shopping centres during twenty four hours. For this purpose, an empirical research was carried out which resulted in a comprehensive analysis of the parking lots of 49 shopping centres in Vilnius City. The research used observation method to determine a design capacity of the parking lots of shopping centres, their occupancy, to additionally define the number of residents living in the closest proximity to the parking lot, the number of flats, the value of flats, the number of working population, the demand for parking spaces, occupancy of the parking lots with cars, etc. The expert method was used to select the main criteria characterizing interaction of the parking lots of shopping centres with the multi-storey housing area. With the help of expert questionnaire the weights and significances of criteria were determined. Using the multiple-criteria methods a priority use of the parking lots of shopping centres for parking of passenger cars was calculated and assessed. The article gives development priorities and outlines the strategy of implementing the given recommendations. This is one of the first attempts to use the parking lots of shopping centres to park passenger cars at night. If the suggested system is put into practice it would help to reduce up to $20 \%$ the demand for parking spaces in the urbanized multi-storey housing areas.

Key Words: Parking lots, shopping center, transport planning, expert, AHP, MCDM.

JEL Classification: C300, R520.

DOI: 10.15240/tul/001/2016-3-012 